\title{
THE SUBTYPES OF PANCREATIC DUCTAL ADENOCARCINOMAS
}

\author{
Kakkar Apeksha, ${ }^{1}$ Choudhuri Jui, ${ }^{2}$ Mukherjee Indraneil ${ }^{3}$ \\ ${ }^{1}$ Grant Medical College, Mumbai, India \\ ${ }^{2}$ Medanta Hospital, Gurgaon, India \\ ${ }^{3}$ Florida Hospital Tampa, Tampa, Florida, USA
}

Primljen/Received 03. 10. 2016. god.

Abstract: Being the $4^{\text {th }}$ leading cause of cancer deaths in the U.S. and with a global increase in incidence, above $80 \%$ of pancreatic cancers are locally advanced or metastatic at the time of diagnosis. As surgical resection is the only hope for a cure, the answer is probably in early screening, proper classification and right therapy. The advancing research will likely lead to a better understanding of Pancreatic Ductal Adenocarcinoma (PDAC) as well as enhance the techniques for screening, diagnosis, accurate subtyping and enable the use of targeted therapy. Thus, instead of clubbing together various subtypes of PDAC for trials, improving the subcategorization will ensure statistical significance for the academicians, and the clinicians would avoid administration of placebo drug to a vast number of patients.

Key words: pancreatic cancer, subtypes, genetic, proteomic, phosphoproteomic.

\section{INTRODUCTION}

Pancreatic cancer is the $4^{\text {th }}$ leading cause of cancer death in the USA, and is increasing globally. The cure rate, although showing improvement, is still very low, approximating at less than 7\%. It is often diagnosed at a very late stage, when curative treatments are limited. Above $80 \%$ of these cancers are locally advanced or metastatic at the time of diagnosis. As surgical resection is the only hope for a cure, the answer is probably in early screening, proper classification and right therapy (1) The advancing research technologies and easy accessibility, will hopefully lead to a better understanding of Pancreatic Ductal Adenocarcinoma (PDAC) as well as enhance the techniques for screening, diagnosis, accurate subtyping and enable the use of targeted therapy.

Though PDAC is the most common form of pancreatic cancer, its causes and risk factors are largely un-
Prihvaćen/Accepted 30. 11. 2016. god.

known. In spite of the emergence of various treatment modalities, very few randomized trials have shown a drastic alteration in PDAC management. This is attributed to inadequate statistical significance leading to the hypothesis that PDAC is an aggregate of many diseases. Scientifically, the fundamental differentiation in PDAC lies in its genetic mutations and variable activation of them. Sporadic mutations (p16, TP53, KRAS, BRAF, SMAD4 mutations) are much more common than inherited genetic mutations and associated syndromes (p16, TP53 mutations). The different prognosis and managements for each PDAC probably stem from these variable genetic mutations (2).

The vast genetic studies on PDAC have failed to affect the clinical decision making, thus, paving way for addition of proteomic data to these studies. Proteomics improves the functional accuracy of data while, genomics is concerned with physical information. In addition to this data, phosphorylation of proteins lets us know about the active proteins.

The challenge has been to Subtype PDAC so that we do not cluster the different types in the same group, wishing one modality will treat all of them. This would help us in designing better future clinical trials. With newer techniques, we have been able to subtype PDAC. These classification systems have not been universally accepted, thus, this field is in a stage of exponential growth and promise. The first classification was tried by Collison and group in 2011. It has been debated and restructured with newer subtyping coming out more recently. We had previously reported 3 classifications in a previous paper (2).

\section{Subtypes}

Collisson et al (3) and his team used Gene expression analysis and used 62 designated gene signatures to subtype Pancreatic Cancer tissue it into "classical", 
"quasi-mesenchymal (QM)", and "exocrine - like". The "Classical" subtyped showed favorable prognosis. The "classical" subtype had high expression of epithelial and adhesion-associated genes. The "Quasi-Mesenchymal)" subtype showed high expression of mesenchyme associated genes and the "exocrine-like" subtype similarly showed relatively high expression of exocrine enzyme genes.

Moffitt et al on genetic analysis subtyped it into two tumor subtypes on the basis of two different tissues. The micro-dissected and analyzed the tumor cells and stromal cells. On the basis of genetic analysis of the ductal cells the subtyping was classified into "classical" and "basal-like" and on the basis of the stromal cells into "normal" and "activated". The "Classical" ductal subtype again showed favorable prognosis when compared to "basal - like". Patients with "activated" stromal subtype had a worse prognosis (4).

To identify metabolomic clustering within PDAC, Daemen A. et al. (5) investigated the PDAC metabolite profile. They quantified 256 metabolites and studied 38 PDAC cell lines. They identified three subtypes that showed different profiles associated with glycolysis, lipogenesis, and redox pathways. A subtype was defined by "reduced proliferative capacity", while the other two showed distinct metabolite levels associated with glycolysis, lipogenesis, and redox pathways. These were named subtypes "glycolytic" and "lipogenic" subtypes. In PDAC clinical samples, functional relevance in disease progression was suggested by the following association: The "lipogenic" subtype is associated with the epithelial "classical" subtype of Collison, with better prognosis, whereas the "glycolytic" subtype is associated with the "Quasi-mesenchymal" subtype of Collison.

Bailey et al (6) identified genes that are consistently mutated in pancreatic cancers. On analysis of gene activity, it revealed four distinct subtypes of PDAC, Squamous, Pancreatic progenitor, Immunogenic and aberrantly differentiated endocrine exocrine-(ADEX).

The primary mutation in "Squamous tumors" was p53 and these tumors were found to have worse prognosis while "Pancreatic progenitor tumors" had abnormal expression of genes involved in early pancreatic development. "Aberrantly Differentiated Endocrine Exocrine -ADEX tumors" had aberrant activity of genes involved in KRAS activation, exocrine, and endocrine differentiation and "Immunogenic tumors" had aberrant activity in genes regulating the immune pathways.

Another study, subtyping the PDAC on the basis of selective signaling networks, provides insight into PDAC biology. Humphrey et al resolved PDAC into subtypes by global phospho-tyrosine profiling. Using immune-affinity coupled high-resolution mass spectrometry, global tyrosine phosphorylation patterns we- re characterized across two large panels of human PDAC cell lines: the ATCC series and TKCC series, resulting in the identification of more than 1,800 tyrosine phosphorylation sites and the consistent classification into three subtypes with distinct phosphorylation profiles (7).

The 3 subtypes characteristic of the ATCC series, were associated with changes in signaling networks associated with: "cell-cell adhesion and epithelial-mesenchyme transition, mRNA metabolism and receptor tyrosine kinase signaling. Further investigation showed that the three subtypes were conserved in the both the series. These receptor tyrosine kinase enriched cell lines exhibited enhanced sensitivity to EGFR inhibitors which may act a prognostic marker for response to therapy.

\section{DISCUSSION}

The premalignant lesions like IPMNs and MCNs are detectable with radiological and endoscopic ultrasound imaging. We are unable to predict accurately which cysts can be safely monitored, and which likely to progress to infiltrating carcinoma. A major help to the clinician was the establishment of consensus guidelines by a consortium of the international association of Pancreatology at a meeting held in Sendai, Japan, in 2006, followed by a revision of the guidelines in 2012 $(8,9)$. Though the original and the revised Sendai guidelines are extremely helpful, they rely on indirect measurements of risk. Studies to validate these guidelines have not been successful in confirming them. Therefore, more reliable markers are needed for the management of individual patients. Many studies correlating the grades of (Pancreatic Intra epithelial Neoplasia) PanIN lesions and genetic mutations have been done. One by Saiki et. al (10) has shown that approximately $45 \%$ of PanIN-I lesions were found to harbor KRAS mutation, thus suggesting that one of the earliest genetic mutations is activation of KRAS. After it the inactivating mutations of CDKN2A may be responsible for PanIN-II and inactivation of TP53 and SMAD4 are generally associated with PanIN-III. Similarly, Fritz et. al (11) found the expression of SPARC is lost in $50 \%$ of low and moderate grade dysplasia, while it is lost in $80 \%$ of the IPMNs with high-grade dysplasia.

\section{CONCLUSION}

In this bioinformatics driven era it would not be prudent for the academicians and clinicians to put all kinds of PDAC in the same arm of a clinical trial. For the academicians, it would only surmount to bias and achieving statistical significance would be very difficult, while for the clinicians, we would be knowingly giving a placebo drug to a vast number of patients. The 
sub-classifications that emerge with the rapidly evolving novel technologies will provide an opportunity to not only better the understanding of the etiology and progress of PDAC, but will also help in targeting the therapy selectively and may give clues to early detection of this aggressive carcinoma, thereby improving the mortality and 5 year survival rates. Therefore, it's wise to follow and grow the growing field of Subtyping the Pancreatic Ductal Adenocarcinoma.

\section{CONFLICT OF INTEREST}

The authors declare that there is no conflict of interest.

\section{Source of Funding}

There were no external funding source for this study.
Abbreviations
PDAC - Pancreatic Ductal Adenocarcinoma
USA - United States of America
TP53 - Tumor Protein p53

KRAS - V-Ki-ras2 Kirsten rat sarcoma viral oncogene homolog: It is a protein encoding Gene.

BRAF - v-Raf murine sarcoma viral oncogene homolog B: It is a protein encoding Gene.

SMAD4 - It is a protein encoding Gene that plays a role in maintaining balance between atrophy and hypertrophy: Mothers against decapentaplegic homolog 4.

QM - Quasi Mesenchymal type of Pancreatic Adenocarcinoma.

ADEX - Aberrantly Differentiated Endocrine eXocrine type of Pancreatic Adenocarcinoma.

ATCC - ATCC is a company in Washington, DC, USA.

TKCC - The Kinghorn Cancer Centre, Australia.

EGFR - Epidermal Growth Factor Receptor.

IPMN - Intraductal papillary mucinous neoplasm.

MCN - Mucinous Cystic Neoplasms.

PanIN - Pancreatic Intra epithelial Neoplasia.

SPARC - Secreted Protein Acidic \& Rich in Cysteine: It is a protein encoding Gene.

\title{
Sažetak
}

\section{PODTIPOVI PANKREASNOG DUKTALNOG ADENOKARCINOMA}

\author{
Kakkar Apeksha, ${ }^{1}$ Choudhuri Jui, ${ }^{2}$ Mukherjee Indraneil ${ }^{3}$ \\ ${ }^{1}$ Grant Medical College, Mumbai, India \\ ${ }^{2}$ Medanta Hospital, Gurgaon, India \\ ${ }^{3}$ Florida Hospital Tampa, Tampa, Florida, USA
}

Karcinom pankreasa predstavlja četvrti po redu uzrok smrti od karcinoma u Sjedinjenim Američkim Državama. Porast incidence kao i činjenica da preko $80 \%$ pankreasnih karcinoma je lokalno uznapredovalo ili sa prisutnim metastatskim promenama u vreme postavljanja dijagnoze, stavlja ga u fokus istraživanja današnjice. S obzirom da je jedina nada za izlečenje hirurška resekcija, unapređenje leži u ranom skriningu, odgovarajućoj klasifikaciji, kao i ispravnoj terapiji. Uznapredovala istraživanja na ovom polju će najverovatnije dovesti do

\section{REFERENCES}

1. Wray CJ, Ahmad SA, Matthews JB, Lowy AM. Surgery for pancreatic cancer: recent controversies and current practice. Gastroenterology. 2005; 128(6): 1626-41.

2. Mukherjee I, Powell B, Parianos M, Downs D, Ross SB. Available technologies and clinical applications of targeted chemotherapy in pancreatic cancer. Cancer Genetics. 2016 Aug 5.

3. Collisson EA, Sadanandam A, Olson P et al. Subtypes of pancreatic ductal adenocarcinoma and their differing responses to therapy. Nat Med. 2011; 17(4): 500-3. boljeg razumevanja pankreasnog duktalnog adenokarcinoma (AKPD), kao i unapređenja tehnika skrininga, dijagnostike, do ažuriranja subtipizacije i omogućavanja upotrebe ciljane terapije. S toga, umesto raportiranja o raznovrsnim subtipovima AKPD, unapređenje subkategorizacije će obezbediti statističku značajnost za akademike, a ujedno će i kliničari izbeći uvođenje placebo leka velikom broju pacijenata.

Ključne reči: karcinom pankreasa, subtipovi, genetika, proteomik, fosfoproteomik.

4. Moffitt RA, Marayati R, Flate EL et al. Virtual microdissection identifies distinct tumor-and stroma-specific subtypes of pancreatic ductal adenocarcinoma. Nat Genet. 2015; 47(10): 1168-78.

5. Daemen A, Peterson D, Sahu N et al. Metabolite profiling stratifies pancreatic ductal adenocarcinomas into subtypes with distinct sensitivities to metabolic inhibitors. Proc. Natl. Acad. Sci. 2015; 112(32): E4410-7.

6. Bailey P, Chang DK, Nones K et al. Genomic analyses identify molecular subtypes of pancreatic cancer. Nature. 2016; 531(7592): 47-52. 
7. Humphrey ES, Su SP, Nagrial AM et al. Resolution of novel pancreatic ductal adenocarcinoma subtypes by global phosphotyrosine profiling. Mol. Cell. Proteomics. 2016; 15 (8)2671-85.

8. Tanaka M, Chari S, Adsay V et al. International consensus guidelines for management of intraductal papillary mucinous neoplasms and mucinous cystic neoplasms of the pancreas. Pancreatology. 2006; 6(1-2) 17-32.

9. Tanaka M, Fernández-Del Castillo C, Adsay V et al. International consensus guidelines 2012 for the management of
IPMN and MCN of the pancreas. Pancreatology. 2012; 12(3): 183-97.

10. Saiki Y, Horii A. Molecular pathology of pancreatic cancer. Pathology international. 2014; 64(1): 10-9.

11. Fritz S, Fernandez-del Castillo C, Mino-Kenudson M et al. Global genomic analysis of intraductal papillary mucinous neoplasms of the pancreas reveals significant molecular differences compared to ductal adenocarcinoma. Ann. Surg. 2009; 249(3): 440-7.

\section{Correspodence to/ Autor za korespodenciju}

Indraneil Mukherjee MD

The Southeastern Center for Digestive Disorders \& Pancreatic Cancer, Advanced Minimally Invasive \& Robotic Surgery,

Florida Hospital Tampa

3000 Medical Park Drive, Suite 500,

Tampa, FL. 33613

Email indraneilm@yahoo.com 